\title{
PELATIHAN MESIN PENGERING KERUPUK MELARAT ELEKTRIK PADA UMKM DESA GRABAGAN KECAMATAN TULANGAN SIDOARJO
}

\author{
Rony HR Fora ${ }^{1)}$, Atmiasri $^{2)}$ dan Linda Dwi Rohmadiani ${ }^{3)}$ \\ ${ }^{1,2}$ Fakultas Teknologi Industri Universitas PGRI Adi Buana Surabaya \\ ${ }^{3}$ Fakultas Teknik Sipil dan Perencanaan Universitas PGRI Adi Buana Surabaya \\ Email: rony@unipasby.ac.id,atmi.asri@unipasby.ac.id,linda@unipasby.ac.id
}

\begin{abstract}
Abstrak
Kerupuk melarat adalah sejenis kerupuk yang menggunakan pasir Lumajang sebagai media penggorengan dengan keuntungan lebih murah, mudah didapat dan tahan lama. Tahapan produksi kerupuk melarat dimulai pengeringan kemudian digoreng. Pengeringan kerupuk melarat Desa Grabagan sangat dipengaruhi oleh cuaca (konvensional), pada musim kemarau membutuhkan waktu 6 jam sedangkan musim penghujan lebih lama kurang lebih 2 hari. Solusi yang ditawarkan oleh tim pelaksana pengabdian kepada masyarakat adalah penggunaan mesin pengering kerupuk melarat elektrik tipe kabinet menggunakan LPG sebagai pemanas. Tujuan program pengabdian kepada masyarakat ini adalah mengembangkan softskill dan hardskill pengusaha kerupuk melarat di Desa Grabagan melalui penggunaan teknologi tepat guna dalam pengeringan kerupuk sehingga semakin meningkatkan produktifitas industri dan efisiensi produksi. Metode yang digunakan adalah sosialisasi, demo penggunaan mesin dan pendampingan. Penggunaan mesin pengering elektrik maka produksi lebih efisien kurang lebih 300\%, lebih higienis, dapat dikontrol temperatur mesin dan menghemat lahan untuk penjemuran.
\end{abstract}

Kata kunci: Efisiensi produksi, Kerupuk melarat, Teknologi tepat guna

\begin{abstract}
Impoverished crackers are a kind of crackers that use Lumajang sand as a frying medium with the advantage of being cheaper, easily obtained and durable. Stages of destitute cracker production begins drying then frying. Drying crackers destitute Grabagan Village is strongly influenced by the weather (conventional), in the dry season it takes 6 hours while the rainy season is more or less 2 days. The solution offered by the community service implementation team is the use of a cabinettype electric cracker dryer using LPG as a heater. The aim of this community service program is to develop soft skills and hard skills of destitute crackers entrepreneurs in Grabagan Village through the use of appropriate technology in drying crackers so as to increase industrial productivity and production efficiency. The method used is socialization, demonstration of the use of machines and assistance. The use of an electric dryer is more efficient production of approximately 300\%, more hygienic, can be controlled by machine temperature and saves land for drying.
\end{abstract}

Keywords: Aappropriate of technology, Destitute crackers, Efficient production 


\section{PENDAHULUAN}

Kerupuk melarat atau kerupuk goreng pasir adalah kerupuk yang menggunakan media pasir Lumajang sebagai media penggorengan. Keuntungan penggorengan menggunakan pasir karena harga murah, mudah didapat dan tidak mudah tengik (Pamilianti, 2014 dan Siswantoro dkk (2009) dalam Ghadafi, 2014). Keuntungan yang didapat diantaranya: produk tidak mudah tengik, nilai kontak panas permukaan (h) pasir cukup besar khususnya pasir sungai yaitu $69,2 \mathrm{~J} / \mathrm{dt} . \mathrm{m}{ }^{2.0} \mathrm{C}$, harga pasir murah, mengurangi ketergantungan minyak goreng (Siswantoro dkk (2009) dalam Ghadafi, 2014). Kerupuk dapat menjadi sumber kalori yang berasal dari pati (dan lemak apabila telah digoreng), serta sumber protein (apabila ikan dan udang benar-benar ditambahkan) (Koswara, 2009).

Kerupuk melarat merupakan kerupuk berbahan dasar pati yang digoreng menggunakan pasir Lumajang yang sudah dibersihkan. Penggorengan kerupuk prosesnya dimulai dari penjemuran kerupuk kemudian digoreng menggunakan alat sederhana. Jumlah produksi 30-40 kg per hari dengan lama pengeringan 1-2 hari tergantung kondisi cuaca serta membutuhkan lahan untuk tempat pengeringan (Fora dkk, 2019). Pengeringan kerupuk bertujuan juga untuk pengawetan, pengurangan ongkos transportasi dan mempertahankan mutu (Koswara, 2009).

Metode pengeringan yang paling umum digunakan adalah metode penjemuran bahan secara langsung dibawah terik matahari atau konvensional seperti Gambar 1 , tetapi metode ini tidak efisien waktu, panas fluktuatif dan terkontaminasi debu dari udara (Karyadi dkk, 2013). Kapasitas produsi kerupuk mengalami penurunan sekitar $10 \%$ di saat musim penghujan sedangkan permintaan pasar cenderung meningkat.
Pengeringan kerupuk pada musim penghujan bisa mencapai 3 hari, bahkan tidak jarang pengeringan gagal sehingga kerupuk pun banyak ditumbuhi jamur (Purnono dkk, 2017).

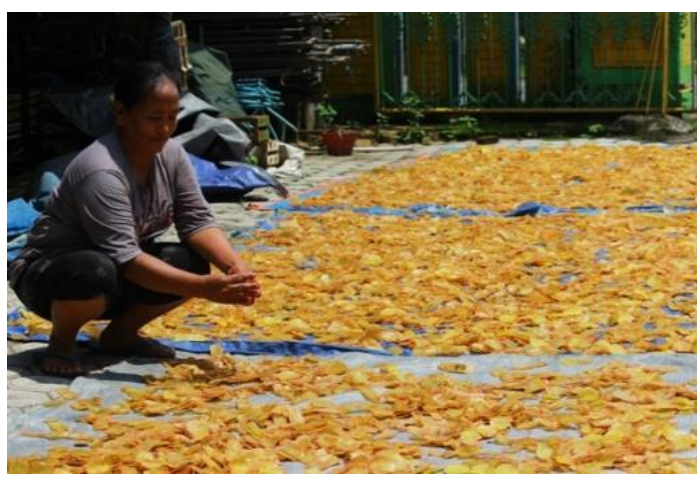

Gambar 1. Pengeringan Kerupuk Secara dijemur

Usaha Mikro Kecil dan Menengah (UMKM) penggoreng kerupuk melarat Desa Grabagan merupakan industri hilir dari industri kerupuk di Desa Tlasih Kecamatan Tulangan. UMKM ini berdiri sejak Tahun 2010. UMKM diatur dalam Undang-Undang No. 20 Tahun 2008 tentang Usaha Mikro Kecil dan Menengah, usaha mikro adalah usaha produktif milik orang perorangan dan/atau badan. Usaha kecil adalah usaha ekonomi produktif yang berdiri sendiri, yang dilakukan oleh orang perorangan atau badan usaha yang buka merupakan anak perusahan atau bukan anak cabang yang dimiliki, dikuasai atau menjadi bagian, baik langsung maupun tidak langsung, dari usaha menengah atau usaha besar yang memenuhi kriteria usaha kecil.

Usaha mikro adalah usaha ekonomi produktif yang berdiri sendiri yang dilakukan oleh perorangan atau badan usaha yang bukan merupakan anak perusahaan atau bukan cabang perusahaan yang dimiliki, dikuasai, atau menjadi bagian baik langsung maupun tidak langsung, dari usaha mikro, 
usah kecil atau usaha besar yang memenuhi kriteria usaha mikro.

Kegiatan pengabdian kepada masyarakat ini diharapkan dapat menjadi soluasi bagi pengusaha penggoreng kerupuk melarat agar dapat meningkatkan produktifitas dan kesejahteraannya. Sasarannya adalah UMKM penggoreng kerupuk melarat Desa Grabagan Kecamatan Tulangan Kabupaten Sidoarjo. Target luaran yang ingin dicapai adalah:

a. Meningkatkan pengetahuan mengenai teknologi tepat guna pengering kerupuk melarat.

b. Mengingkatkan ketrampilan UMKM dalam menggunakan mesin pengering kerupuk melarat

c. Meningkatkan produktifitas dan kesejahteraan UMKM

\section{METODE PELAKSANAAN}

Metode pelaksanaan pengabdian ini sebagai berikut:

a. Sosialisasi: pada kegiatan ini kepada peserta dijelaskan cara penggunaan mesin pengering kerupuk melarat elektrik dan bagian-bagian dari mesin.

b. Demonstrasi: pada kegiatan ini dilakukan demonstrasi cara penggunaan mesin.

c. Kegiatan pendampingan dilakukan untuk memantau ketrampilan pengusaha dalam menggunakan mesin pengering elektrik. Evaluasi hasil dilakukan setelah pengeringan kerupuk melarat menggunakan mesin.

\section{HASIL DAN PEMBAHASAN}

Kegiatan PKM ini dimulai dengan tahap persiapan.Tahap persiapan terdiri atas identifikasi permasalahan mitra, penyusunan proposal, koordinasi antara tim pengabdian dengan mitra mencakup waktu dan teknis pelaksanaan serta persiapan alat dan bahan pelatihan.

Perencanaan dan pembuatan alat yaitu:

a. Mesin pengering kerupuk elektrik ukuran $60 \times 40 \times 130 \mathrm{~cm}$

b. Bahan stainlesteel agar lebih awet dan mudah perawatannya

c. Otomatis heat sensor antara $0^{0}-20^{0}$ Celcius

d. Output blower 2 inci

e. Kapasitas $5 \mathrm{~kg}$ per unit mesin

f. Loyang

g. Tabung Gas LPG $3 \mathrm{~kg}$ sebagai sumber pemanas

Bahan yang digunakan adalah kerupuk basah seperti pada Gambar 2.

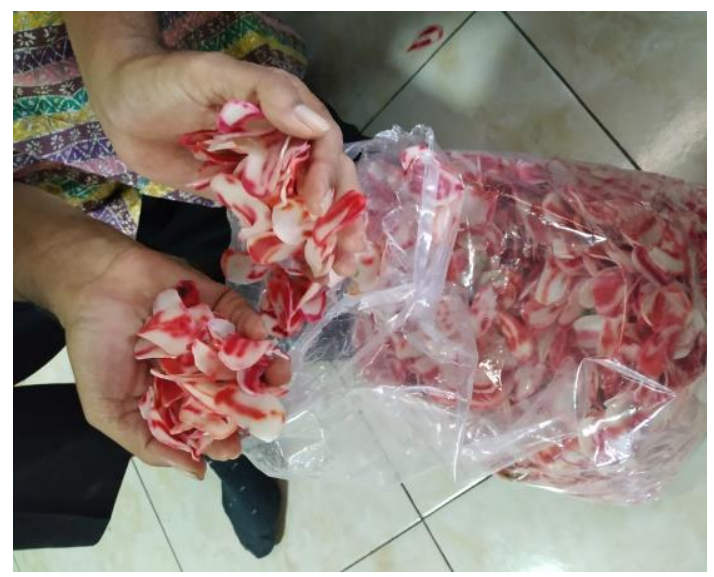

Gambar 2. Kerupuk Melarat Mentah Yang Sudah Dikeringkan

Mesin pengering yang dihasilkan dapat dilihat pada Gambar 3. Mesin pengering bertipe cabinet dryer, kerupuk yang dikeringkan diletakan di atas rak (cabinet). Sumber panas mesin adalah nyala api kompor diletakkan di bagian bawah dari mesin. Perpindahan panas dari nyala api kompor ke pelat yang ada di atasnya berlangsung secara konveksi bebas dan besarnya laju perpindahan panas tergantung dari perbedaan temperatur udara panas dan temperatur permukaan plat stabilisator (Walujodjati \& Darmanto, 2005). 


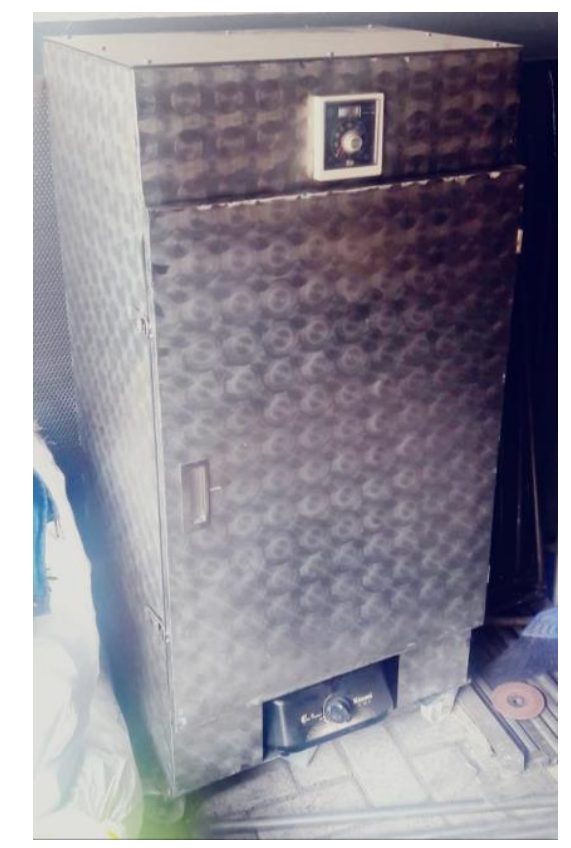

Gambar 3. Mesin Pengering Kerupuk

Elektrik Tipe Cabinet Rak 7 Susun

Sosialisasi mengenai teknologi mesin pengering kerupuk elektrik denan menggunakan metode ceramah dilaksanakan pada tanggal 30 Juli 2019 mulai jam 09.00 sampai 12.00 WIB dihadiri oleh UMKM kerupuk melarat sebanyak 20 orang dan aparat desa (Gambar 4 dan 5). Tim pengabdian kepada masyarakat juga melakukan demo penggunaan mesin pengering kerupuk elektrik dan sesi tanya jawab. Hasil penggorengan kerupuk melarat seperti pada Gambar 6. Para peserta sangat antusias dengan kegiatan transfer pengetahuan ini, hal ini ditunjukkan dengan adanya pertanyaan-pertanyaan yang ada kaitannya dengan materi.

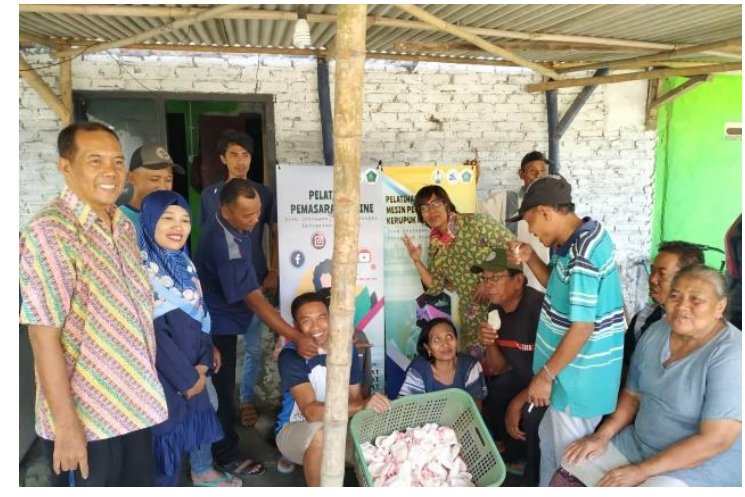

Gambar 4. Sosialisasi dan Demo Penggunaan Mesin Pengering Kerupuk Elektrik

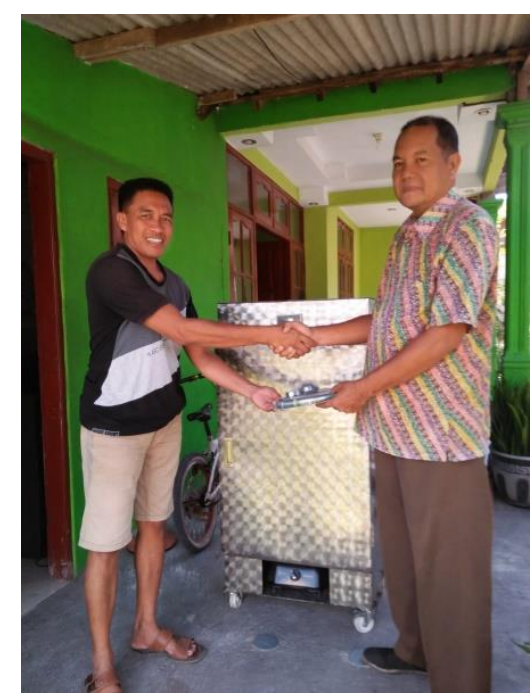

Gambar 5. Serah Terima Mesin Pengering Kerupuk Elektrik

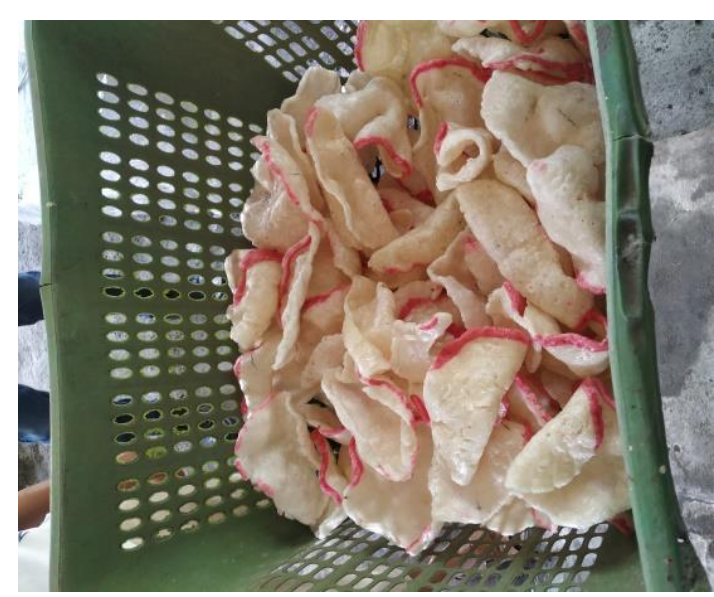

Gambar 6. Kerupuk Melarat Yang Sudah Digoreng 
Evaluasi program dengan cara membandingkan kondisi mitra sebelum dan sesudah program. Indikator keberhasilan program adalah:

a. Adanya peningkatan pengetahuan mengenai operasional mesin pengering kerupuk melarat

b. Adanya perubahan teknologi produksi dari pengering alami atau sinar matahari berubah menggunakan mesin pengering elektrik.

c. Kualitas kerupuk menjadi lebih higienis karena dilakukan secara tertutup daripada dijemur di halaman rumah

d. Waktu pengeringan kerupuk lebih cepat menggunakan mesin daripada dijemur sehingga lebih efisien waktu. Waktu produksi 3 jam terbagi atas 2 jam produksi (pengeringan dan penggorengan kerupuk) dau 1 jam untuk pengemasan.

e. Tingkat kepuasan pengusaha dalam memanfaatkan mesin

Hasil yang dicapai dalam pelatihan mesin pengering ini yaitu:

a. Pengusaha UMKM dapat mengoperasikan mesin pengering kerupuk elektrik secara mandiri atau berkelompok

b. Adanya peningkatan wawasan pengusaha UMKM Kerupuk Melarat mengenai teknologi pengeringan kerupuk elektrik

c. Pengusaha UMKM antusias mengikuti pelatihan sehingga menginginkan adanya kegiatan lanjutan seperti pelatihan desain kemasan dan pemasaran online.

Kapasitas pengeringan $5 \mathrm{~kg}$ per 15 menit, sehingga kerupuk mitra sebanyak 40 $\mathrm{kg}$ dapat dikeringkan dalam waktu 2 jam, sebelumnya, saat pengeringan tanpa mesin, dikeringkan selama 6 jam. Kondisi ini menunjukkan adanya efisiensi waktu sebesar $300 \%$. Kelebihan lain dari penggunaan mesin pengering ini adalah a. Hasil pengeringan lebih bersih, tertutup, terlindungi dari debu dan kotoran lain di udara.

b. Pengeringan dapat dilakukan kapan saja, tidak tergantung dari cuaca dan terik matahari.

c. Tidak membutuhkan ruangan yang luas.

d. Dari segi kualitas, tidak merubah cita rasa kerupuk.

e. Suhu dan waktu pemanasan dapat dikontrol.

\section{KESIMPULAN}

Permasalahan mitra dalam hal pengeringan dapat teratasi dengan adanya mesin pengering kerupuk melarat elektrik bahkan dapat meningkatkan produksi dan lebih hemat waktu. Adanya peningkatan pengetahuan dan ketrampilan pengusaha kerupuk melarat dalam menggunakan teknologi pengering kerupuk elektrik. Saran untuk pengabdian kepada masyarakat lanjutan tentang pelatihan desain kemasan yang marketable dan pemasaran online sehingga dapat memperluas area pemasaran kerupuk.

\section{UCAPAN TERIMA KASIH}

Terima kasih diucapkan kepada DPRM Kemenristekdikti dan LPPM Universitas PGRI Adi Buana Surabaya atas terselenggaranya pengabdian kepada masyarakat Skema PKM Tahun Anggaran 2019 di Desa Grabagan Kecamatan Tulangan Kabupaten Sidoarjo. Terima kasih diucapkan kepada aparat desa dan para pengusaha Kerupuk Melarat Desa Grabagan atas penggunaan mesin ini. 


\section{REFERENSI}

Fora, RHR, Atmiasri dan Rohmadiani, LD. 2019. Penerapan Mesin Penggoreng Elektrik Sebagai Upaya Peningkatan Produksi UMKM Kerupuk Melarat. Prosiding Seminar Nasional SMONAGENES MIPA Universitas Brawijaya Malang.

Ghadafi, M. 2014. Modifikasi Pengolahan Kerupuk Pasir Tinggi Kalsium Plus-Plus Dengan Ceker Ayam/ Kaki Ayam PPI Dunia 2014.

https://www.academia.edu/8200837/MOD IFIKASI_PENGOLAHAN_KERUPUK_ PASIR_TINGGI_KALSIUM_PLUSPLUS_DENGAN_CEKER_AYAM_KA KI_AYAM_PPI_DUNIA_2014.

Karyadi, JNW, Supeno, D dan Bintoro, N. 2013. Pengeringan Kerupuk Singkong Menggunakan Pengering Tipe Rak. Seminar Nasional Sains \& Teknologi V Lembaga Penelitian Universitas Lampung.

https://repository.ugm.ac.id/33118/1/9292.pdf.

Koswara, Sutrisno. 2009. Pengolahan Aneka Kerupuk. Ebookpangan.com. http://tekpan.unimus.ac.id/wpcontent/uploads/2013/07/PENGOLAHAN -ANEKA-K-E-R-U-P-U-K.pdf.

Undang-Undang No. 20 Tahun 2008 tentang Usaha Mikro, Kecil dan Menengah.

Pamilianti, PY. 2014. Uji Kandungan Protein Pada Kerupuk Ketan Dengan Penambahan Tepung Keong Mas Dan Tepung Kerang Dara (Anadara Granosa). http://eprints.ums.ac.id/28492/.

Prasetyawan, Y; Singgih, ML; Putrianingsih, E; Andriani, Y dan Ziyad, M. 2014. Peningkatan Produktivitas Usaha Kecil Menengah Kerupuk Udang Melalui Perancangan Pengeringan Dan Pengemasan. Jurnal Metris Vol. 15 Hal. 7-14. http://ojs.atmajaya.ac.id/index.php/metris/ article/view/29.

Purnomo, Sulistyaningsih, D dan Santoso, REWA. 2017. Implementasi Alat pengering Cabinet Dryer Untuk Mnegatasi Masalah Pengeringan Kerupuk Pada Usaha Kecil Kerupuk. Prosiding Seminar Nasional Publikasi Hasil-Hasil Penelitian dan Pengabdian Masyarakat Universitas Muhammadiyah Semarang.

https://jurnal.unimus.ac.id/index.php/psn1 2012010/article/download/2929/2852.

Siswantoto, Rahardjo, B, Bintoro, N dan Hastuti, P. 2011. Pemodelan Matematik Perubahan Parameter Mutu Kerupuk Selama Penggorengan Dengan Pasir. Jurnal Teknologi dan Industri Pangan Vol. XXII No. 1.

Walujodjati, A dan Darmanto. 2005. Rancang Bangun Mesin Pengering Kerupuk Untuk Industri Kecil Kerupuk. Jurnal Momentum Vol. 1 No. 1. https://publikasiilmiah.unwahas.ac.id/inde x.php/MOMENTUM/article/view/7/7. 